\title{
Editorial
}

\section{O processo de formalização e consolidação da Terapia Ocupacional no Brasil: percepções sobre o crescimento da produção científica na área}

\author{
Marta Carvalho de Almeida ${ }^{1}$ \\ Elisabete Ferreira Mângia ${ }^{2}$
}

Tomando como eixo de reflexão o estado da arte e a produção de conhecimento em Terapia Ocupacional no Brasil, temos observado atualmente um notável crescimento de publicações da área, especialmente no contexto de eventos científicos.

Tornou-se mais freqüente a publicação de livros de terapeutas ocupacionais, assim como de capítulos que integram edições temáticas que privilegiam a abordagem multidisciplinar ou interdisciplinar. Vemos também novos livros didáticos, organizados e produzidos por terapeutas ocupacionais. Paralelamente a isso tem crescido o interesse de muitas editoras na organização e publicação de livros em nossa área. Esse interesse se faz notar na intensificação dos contatos de editores com docentes e grupos de pesquisa ativos em nosso país.

Quanto à consolidação de revistas específicas da área, sabemos que esse é o principal instrumento de validação da terapia ocupacional - enquanto área especifica de conhecimento - e que, conjuntamente à criação e consolidação de programas de pós-graduação, constitui o mais importante e difícil desafio a ser enfrentado hoje. Temos visto que ao nosso esforço na manutenção da Revista de Terapia Ocupacional da USP soma-se a contribuição de colegas de todo o país e, embora ainda sendo a única revista indexada da área, integramos um pequeno conjunto de periódicos que mesmo pequeno se mantém ativo - certamente graças ao esforço e dedicação dos diferentes grupos que os coordenam e de seus colaboradores. A despeito das inúmeras

\footnotetext{
${ }^{1}$ Prof. Dra. do Curso de Terapia Ocupacional do Departamento de Fisioterapia, Fonoaudiologia e Terapia Ocupacional da FMUSP ${ }^{2}$ Prof. Dra. do Curso de Terapia Ocupacional do Departamento de Fisioterapia, Fonoaudiologia e Terapia Ocupacional da FMUSP. Endereço para correspondência: Departamento de Fisioterapia, Fonoaudiologia e Terapia Ocupacional da Faculdade de Medicina da Universidade de São Paulo. Rua Cipotânea, 51. Cidade Universitáira - CEP: 05360-000 - São Paulo, SP.
} 
dificuldades implicadas na viabilização desses veículos, eles testemunham o contínuo interesse da categoria na formalização dos discursos que expressam a singularidade e conferem identidade ao campo profissional.

Enfim, embora esse fenômeno ocorra de forma compatível com a dimensão da terapia ocupacional no Brasil, e imerso em um contexto onde ainda são grandes as dificuldades para reflexão, formalização e sistematização da produção intelectual, cultural e científica, não resta duvida de que vivemos um período de crescimento da produção e difusão da terapia ocupacional. Para onde nos remete esse momento? Quais elos poderiam ser traçados ao pensarmos esse processo em sua conexão com contextos assistenciais, educacionais, sociais?

Considerando a multiplicidade que caracteriza o processo de formalização discursiva da terapia ocupacional brasileira (MÂNGIA, 1999, p.56), seria bastante importante que pudéssemos intensificar a abertura de espaços de discussão, de debates, de reflexões. Espaços nos quais pudéssemos avaliar criticamente nosso processo rumo à consolidação da terapia ocupacional como um campo de produção discursiva. Espaços que, ao reconhecer desafios e perspectivas, mantivesse o processo aquecido e fecundo.

\section{REFERÊNCIA}

Mângia, E. F. Terapia ocupacional: práticas, discursos e a questão da legitimidade científica. Rev. Ter. Ocup. Univ. São Paulo, v. 10, n. 2/3, p. 55-59, 1999. 